\title{
GAMBARAN PENGETAHUAN MASYARAKAT TENTANG RESIKO PENYAKIT DIABETES MELLITUS DI KECAMATAN PAKISAJI KABUPATEN MALANG
}

\author{
Bayu Jaya Noor Arisma \\ Moch Yunus \\ Erianto Fanani \\ Universitas Negeri Malang \\ bayujayanoor72@gmail.com
}

\begin{abstract}
Diabetes mellitus cases in Indonesia by Riskesdas (2007) is the sixth cause of death disease (5.8\%) and by Depkes (2012) in Indonesia there were 102,399 cases. In 2030 Indonesian people with diabetes mellitus estimated as much as 21.3 million. The incidence of diabetes mellitus in Pakisaji's Puskesmas is 1164 incidents. The purpose of this research is to know the overview of public knowledge about the risks of diabetes mellitus at Pakisaji, Malang. This research method is a descriptive analytical research. The research using rapid survey method. The population is the society with the age of $>40$ years old in district Pakisaji. The number of samples are taken from 254 of 12 villages in the Sub-District of Pakisaji with the cluster random sampling technique and random sampling technique as the appropriate rules of rapid survey. The results of the research is the percentage of public knowledge about the risks of diabetes mellitus in District of Pakisaji like eating patterns the percentage of peopole who know about $63 \%$, physical activity (56,5\%), stress (50\%), smoking (45\%), alcohol (56\%), hypertension (60\%), obesity (51\%), age (64.5\%), generation (78\%), and gender (64.5\%). The average result value of the public knowledge in district Pakisaji Malang about the risk of diabetes mellitus disease is less.
\end{abstract}

Keywords: diabetes mellitus, knowledge, risk

\begin{abstract}
Abstrak: Data diabetes mellitus di Indonesia menurut Riskesdas (2007) menempati urutan keenam penyakit penyebab kematian $(5,8 \%)$ dan di Indonesia menurut Depkes (2012) terdapat 102.399 kasus diabetes mellitus. Diperkirakan pada tahun 2030 angka diabetes mellitus (diabetisi) adalah sebanyak 21,3 juta jiwa. Angka kejadian diabetes mellitus di Puskesmas Pakisaji sejumlah 1164 kejadian. Penelitian ini bertujuan untuk mengetahui gambaran pengetahuan masyarakat tentang resiko penyakit diabetes mellitus di Kecamatan Pakisaji Kabupaten Malang. Metode penelitian ini adalah penelitian deskriptif analitik. Penelitian ini menggunakan metode rapid survey atau survei cepat. Populasi adalah masyarakat usia $>40$ tahun di kecamatan Pakisaji kabupaten Malang. Jumlah sampel sebesar 254 diambil dari 12 desa di kecamatan Pakisaji dengan teknik cluster random sampling dan random sampling sesuai kaidah rapid survey. Hasil penelitian dari 254 responden persentase pengetahuan masyarakat yang tahu tentang resiko penyakit diabetes mellitus seperti pola makan, masyarakat yang tahu bahwa pola makan merupakan faktor resiko diabetes mellitus sebanyak 63\%, aktivitas fisik 56,5\%, stres 50\%, merokok 45\%, alkohol 56\%, hipertensi $60 \%$, obesitas $51 \%$, usia $64,5 \%$, keturunan $78 \%$, dan jenis kelamin $64,5 \%$. Sehingga dari nilai pengetahuan masyarakat di Kecamatan Pakisaji Kabupaten Malang tentang resiko penyakit diabetes mellitus masuk kategori kurang.
\end{abstract}

Kata kunci: diabetes mellitus, pengetahuan, resiko 
Menurut Riset Kesehatan Dasar (Riskesdas) tahun 2007 diabetes di Indonesia menempati urutan keenam penyakit penyebab kematian $(5,8 \%)$ setelah stroke, tuberkulosis, hipertensi, cedera, dan perinatal. Diabetes juga sebagai penyebab kematian pada kelompok usia 45-54 di daerah perkotaan menduduki peringkat ke-2 yaitu $14,7 \%$ dan daerah pedesaan diabetes menduduki peringkat ke-6 yaitu $5,8 \%$ (PERKENI, 2011).

Global status report on NCD World Health Organization (WHO) tahun 2010 melaporkan bahwa 60\% penyebab kematian semua umur di dunia karena penyakit tidak menular, salah satunya adalah diabetes mellitus yang menduduki peringkat ke-6 sebagai penyebab kematian. Berdasarakan data Departemen

Kesehatan Republik Indonesia (2012) terdapat 102.399 kasus

diabetes mellitus. Indonesia diperkirakan pada tahun 2030 akan memiliki penyandang diabetes mellitus (diabetisi) sebanyak 21,3 juta jiwa (Depkes RI, 2013).

Diabetes mellitus merupakan masalah global yang insidennya semakin meningkat. Diabetes mellitus menyebabkan 1,5 juta kematian pada tahun 2012 yang mana glukosa darah tinggi dari angka normal bertanggung jawab terhadap 2,2 juta kematian tambahan sebagai akibat dari peningkatan risiko penyakit kardiovaskular dan lainnya, dengan total 3,7 juta kematian terkait dengan kadar glukosa darah pada tahun 2012. Banyak dari kematian $(43 \%)$ terjadi di bawah usia 70 . Pada tahun 2014, 422 juta orang di dunia menderita diabetes mellitus dengan prevalensi $8,5 \%$ di antara populasi orang dewasa. Prevalensi diabetes mellitus terus meningkat selama 3 dekade terakhir dan tumbuh paling cepat di negara-negara berpenghasilan rendah dan menengah (WHO, 2016).

Prevalensi diabetes mellitus di kabupaten Malang pada tahun 2015 terdapat sejumlah 1684 kasus, yang angka terbanyak terdapat pada rentang usia 40-69 tahun yaitu 943 kasus. Diabetes mellitus secara

keseluruhan menjadi penyakit terbanyak nomer 2 dari yang tercatat dari semua puskesmas di kabupaten Malang (Dinkes Kabupaten Malang, 2016).

Data rekapitulasi dari Puskesmas Pakisaji tahun 2015 angka kejadian diabetes mellitus di Kecamatan Pakisaji Kabupaten Malang masuk dalam 10 besar kejadian penyakit terbanyak yaitu sejumlah 1164 kejadian, dimana angka kejadian paling tinggi terjadi di bulan November yaitu 131

kejadian. (Puskesmas Pakisaji, 2016).

Pengetahuan merupakan salah satu variabel penting yang menunjang insiden dan prevalensi kasus penyakit diabetes mellitus di kecamatan Pakisaji. Salah satu faktor yang mempengaruhi pengetahuan menurut Notoatmojo (2010) adalah tingkat pendidikan, di kecamatan Pakisaji tingkat pendidikan rata-rata paling banyak adalah SD dengan kisaran 35\%, SMP dengan kisaran persentase $27 \%$, SMA dengan kisaran persentase $23 \%$ dan $10 \%$ terbagi dalam lulusan pendidikan tinggi (Diploma dan Sarjana) serta sisanya merupakan yang tidak sekolah atau tidak tamat SD, Angka tersebut merupakan jumlah penduduk usia lebih dari 25 tahun dari total populasi di kecamatan Pakisaji yang berjumlah 84.964 jiwa (BPS Kabupaten Malang, 2015). 
Pengetahuan adalah hasil dari tahu yang terjadi melalui proses sensoris khususnya mata dan telinga terhadap suatu objek tertentu. Proses adopsi perilaku, menurut Rogers (dalam Notoatmodjo, 2007) adalah sebelum seseorang mengadopsi sesuatu di dalam diri orang tersebut suatu proses yang berurutan yaitu: Awareness (kesadaran), Interest (tertarik), Evaluating (menimbangnimbang), Trial (mencoba), Adaptation (adaptasi).

Diabetes mellitus adalah penyakit dengan gangguan metabolisme (metabolic syndrome) dari distribusi gula oleh tubuh. Penderita diabetes mellitus tidak mampu memproduksi hormon insulin dalam jumlah cukup, atau tubuh tidak dapat menggunakannya secara efektif sehingga terjadi kelebihan gula di dalam darah (Irianto, 2014).

Faktor resiko menurut American Diabetes Association (ADA) adalah karakteristik, tanda atau kumpulan gejala pada penyakit yang diderita individu yang secara statistik berhubungan dengan peningkatan kejadian kasus baru berikutnya (beberapa individu lain pada suatu kelompok masyarakat). Karakteristik, tanda atau kumpulan gejala pada penyakit yang diderita individu dan ditemukan juga pada individu-individu yang lain bisa dirubah dan ada juga yang tidak dapat bisa dirubah atau tepatnya) Faktor resiko yang tidak dapat dimodifikasi misalnya umur dan genetik, 2) Faktor resiko yang dapat dimodifikasi misalnya kebiasaan merokok atau latihan olahraga.

Faktor resiko diabetes mellitus terbagi menjadi 2 yaitu faktor resiko yang tidak dapat dimodifikasi dan faktor resiko yang dapat dimodifikasi. Faktor resiko yang tidak dapat dimodifikasi: umur, jenis kelamin, bangsa dan etnik, faktor keturunan, riwayat menderita diabetes gestasional, dan riwayat melahirkan bayi dengan berat badan lahir lebih dari 4000 gram. Sedangkan faktor resiko yang dapat dimodifikasi: obesitas, aktifitas fisik yang kurang, hipertensi, stres, pola makan, penyakit pada pankreas:

pankreatitis, neoplasma, fibrosis kistik, dan alkohol (Tjokroprawiro, 2006).

Tujuan dari penelitian ini adalah untuk mengetahui gambaran pengetahuan masyarakat tentang resiko penyakit diabetes mellitus di kecamatan Pakisaji kabupaten Malang.

\section{METODE}

Penelitian ini merupakan penelitian epidemiologi deskriptif analitik. Rancangan penelitian menggunakan metode Rapid Survey

atau survei cepat. Lokasi pengambilan data di semua desa yang ada di Kecamatan Pakisaji Kabupaten Malang dan pengambilan data dilakukan pada bulan JanuariFebruari tahun 2017.

Populasi adalah masyarakat usia >40 tahun di kecamatan Pakisaji kabupaten Malang. Jumlah sampel sebesar 254 diambil dari 12 desa di kecamatan Pakisaji dengan teknik cluster random sampling dan random sampling sesuai kaidah rapid survey. Teknik analisis dalam penelitian ini adalah analisis statistik deskriptif dengan software komputer.

Analisis

instrumen menggunakan aspek aspek yang mempengaruhi pengetahuan dan hasil akan di analisis dengan menggunakan pembagian tingkatan pengetahuan menurut Erlinawati 
(2007) tingkat pengetahuan ada beberapa kategori sebagai berikut: 1) Pengetahuan baik: rata-rata nilai 85 $100,2)$ Pengetahuan cukup baik: rata-rata nilai 70-84, 3) Pengetahuan kurang: rata-rata nilai 50-69, 4) Pengetahuan sangat kurang: rata-rata nilai kurang dari 50.

\section{HASIL}

Berikut adalah tabel skor dan hasil pengetahuan berdasarkan Desa di Kecamatan Pakisaji Kabupaten Malang:

Tabel 1 Skor dan Hasil Pengetahuan berdasarkan Desa

\begin{tabular}{ccccc}
\hline No & Nama Desa & Jumlah Responden & $\begin{array}{c}\text { Skor } \\
\text { (rata-rata) }\end{array}$ & Hasil \\
\hline 1 & Permanu & 16 & 68,37 & Kurang \\
2 & Karangpandan & 15 & 57,14 & Kurang \\
3 & Glanggang & 14 & 69,52 & Kurang \\
4 & Sutojayan & 14 & 65,71 & Kurang \\
5 & Wonokerso & 14 & 52,55 & Kurang \\
6 & Karangduren & 21 & 61,36 & Kurang \\
7 & Pakisaji & 23 & 61,22 & Kurang \\
8 & Jatisari & 18 & 61,5 & Kurang \\
9 & Wadung & 18 & 61,11 & Kurang \\
10 & Genengan & 24 & 63,18 & Kurang \\
11 & Kebonagung & 50 & 61,37 & Kurang \\
12 & Kendalpayak & 27 & 65,6 & Kurang \\
& Total & 254 & 61,9 & Kurang \\
\hline
\end{tabular}

Tabel 1 menunjukkan bahwa dari 12 desa di kecamatan Pakisaji desa dengan skor tertinggi ada pada desa Glanggang sedangkan skor terendah ada pada desa Wonokerso. Rata-rata skor pengetahuan masyarakat di kecamatan Pakisaji adalah 61,9. Sehingga hasil pengetahuan masyarakat di kecamatan Pakisaji masuk kategori kurang.

Berikut ini merupakan persentase hasil pengetahuan masyarakat di Kecamatan Pakisaji Kabupaten Malang:

Pengetahuan

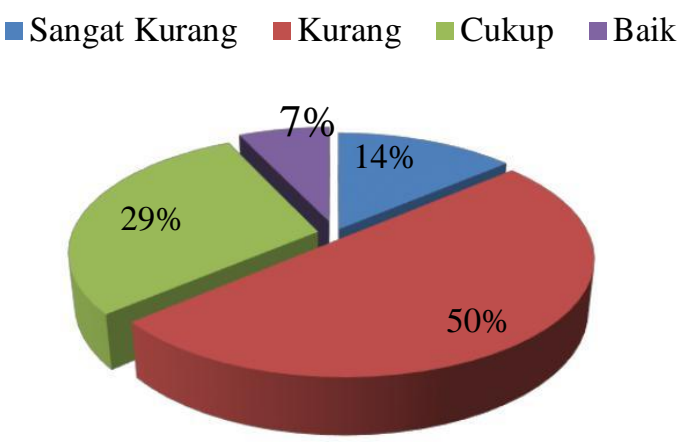

Gambar 1 Pengetahuan Masyarakat di Kecamatan Pakisaji Kabupaten Malang

Gambar 1 dapat disimpulkan yaitu jumlah responden dengan pengetahuan kategori sangat kurang sebanyak $14 \%$ dari 254 responden, kategori kurang $50 \%$ dari 254 responden, kategori cukup 29\% dari 
254 responden, dan kategori baik ada 9\% dari 254 responden. Sehingga tingkat pengetahuan tentang pengetahuan resiko penyakit diabetes mellitus di kecamatan Pakisaji masuk dalam kategori kurang (50\%).

\section{Pendidikan}

Pendidikan masyarakat dari kecamatan Pakisaji sebanyak 35\% adalah Sekolah Dasar, dan 27\% adalah Sekolah Menengah Pertama, 23\% adalah Sekolah Menengah Atas dan $10 \%$ Pendidikan tinggi. Hasil pengetahuan masyarakat tentang resiko diabetes mellitus berbanding lurus dengan tingkat pendidikan, skor tertinggi yaitu 70,6 (kategori cukup) ada pada masyarakat dengan pendidikan tinggi.

\section{Usia}

Rata-rata usia penduduk di kecamatan Pakisaji Kabupaten Malang adalah usia 40-49 tahun.

Hasil pengetahuan masyarakat tentang resiko diabetes mellitus dengan usia 40-49 tahun memiliki skor 61,8 (kategori kurang).

\section{Pekerjaan}

Sekitar 8.024 orang di kecamatan Pakisaji Kabupaten Malang bekerja sebagai karyawan (Swasta). Hasil pengetahuan masyarakat tentang resiko diabetes mellitus dengan pekerjaan Swasta memiliki skor 61,4 (kategori kurang).

\section{Jenis Kelamin}

Jenis Kelamin penduduk di Kecamatan Pakisaji Kabupaten Malang sebanyak 59\% adalah perempuan dan $41 \%$ laki-laki. Hasil pengetahuan masyarakat tentang resiko diabetes mellitus dengan jenis kelamin laki-laki memiliki skor 61,2 dan perempan memiliki skor 62 (kategori kurang).

\section{PEMBAHASAN \\ Pendidikan}

Pendidikan masyarakat dari kecamatan Pakisaji sebanyak $>30 \%$ adalah Sekolah Dasar, dan $>20 \%$ adalah Sekolah Menengah Pertama, sehingga berbanding lurus dengan hasil pengetahuan yang menyatakan kurang dan nilai skor antara masyarakat yang berpendidikan

tinggi lebih tinggi daripada masyarakat yang berpendidikan SMA, SMP, dan SD. Menurut Hary (dalam Hanifah, 2010) menyebutkan bahwa tingkat pendidikan turut pula menentukan mudah tidaknya seseorang menyerap dan memahami pengetahuan yang mereka peroleh pada umumnya semakin tinggi pendidikan seseorang makin baik pula pengetahuannya. Pendidikan merupakan jenjang pendidikan formal terakhir yang pernah diikuti oleh seseorang. Orang yang tingkat pendidikannya tinggi biasanya akan memiliki pengetahuan tentang kesehatan (Legumen, 2013). Dengan adanya pengetahuan tersebut orang akan memiliki kesadaran dalam menjaga kesehatannya (Irawan, 2010). Pembagian tingkat pendidikan antara lain (Notoatmodjo, 2007):

Pendidikan Dasar

(SD, SMP/Sederajat), Pendikan Menengah (SMA/Sederajat), dan Pendidikan

Tinggi (Akademik/Perguruan Tinggi). Tingkat pendidikan memiliki pengaruh terhadap pengetahuan masyarakat terhadap resiko kejadian diabetes mellitus dan atau kejadian diabetes mellitus, Pendidikan responden sebanyak 39\% adalah sekolah dasar (SD) sehingga pengetahuan masyarakat masuk kategori kurang. 
Usia

Menurut Nursalam (dalam Hanifah, 2010) usia individu terhitung mulai dilahirkan sampai saat ini (dalam tahun). Semakin cukup usia, tingkat kematangan seseorang akan lebih matang dalam berfikir dan bekerja. Dari segi kepercayaan masyarakat, seseorang yang lebih dewasa akan lebih dewasa akan lebih dipercaya dari orang belum cukup kedewasanya.

Ahmadi (dalam Hanifah, 2010) juga mengemukakan bahwa memang daya ingat itu salah satunya dipengaruhi oleh usia. Usia masyarakat 40-49 tahun merupakan masa dimana seharusnya sudah masuk kategori matang tetapi secara skor usia 50-59 tahun memiliki nilai lebih tinggi daripada usia 40-49 dikarenakan masyarakat usia 50-59 memiliki pengalaman lebih karena usia 50-59 tahun terdapat jumlah penderita diabetes mellitus lebih banyak daripada usia 40-49 tahun. Sedangkan usia $>60$ juga sama banyaknya dengan usia 50-59 tahun akan tetapi secara kognitif dan penerimaan informasi sangat kurang daripada usia 40-49 tahun dan 50-59 tahun sehingga memiliki skor kurang.

\section{Penelitian antara usia dengan kejadian diabetes mellitus} menunjukan adanya hubungan yang signifikan. Kelompok usia < 45 tahun merupakan kelompok yang kurang berisiko menderita diabetes mellitus. Resiko pada kelompok ini 72 persen lebih rendah dibanding kelompok umur $\geq 45$ tahun. Menurut Iswanto (dalam Legumen, 2013) juga menemukan bahwa ada hubungan yang signifikan antara usia dengan kejadian diabetes mellitus. Studi yang dilakukan Sanjaya (2009) juga menemukan bahwa kelompok usia yang paling banyak menderita diabetes mellitus adalah kelompok usia 45-55 (47,5\%). Peningkatan diabetes risiko diabetes seiring dengan usia. Adanya proses penuaan menyebabkan berkurangnya kemampuan sel $\beta$ pankreas dalam memproduksi insulin (Sanjaya, 2009). Sehingga usia 50-59 tahun dan $>60$ tahun memiliki resiko lebih besar terkena diabetes mellitus dan atau memiliki riwayat terkena diabetes mellitus.

\section{Pekerjaan}

Jenis pekerjaan erat kaitannya dengan kejadian diabetes mellitus. Pekerjaan seseorang mempengaruhi tingkat aktivitas fisiknya. Misalnya IRT yang secara aktivitas tidak rendah karena melakukan perkerjaan seperti menyapu, mencuci, memasak dan lain-lain. Berdasarkan analisis hubungan antara pekerjaan dengan kejadian diabetes mellits tipe 2, didapatkan bahwa tidak ada hubungan yang signifikan antara pekerjaan dengan kejadian diabetes mellitus tipe 2 (Fatimah, 2015). Pekerjaan dalam pemenuhan hasil pengetahuan dapat diukur dari bidang pekerjaan yang ditekuni oleh seseorang. Pengetahuan baik ada pada kelompok responden yang bekerja sebagai PNS. Hal ini sesuai dengan yang diuraikan Situmorang (2009) bahwa lingkungan pekerjaan

dapat menjadikan seseorang memperoleh pengalaman dan pengetahuan baik secara langsung maupun secara tidak langsung, demikian juga yang terlihat dalam kelompok responden pekerjaan PNS. PNS 80-90\% pekerja PNS merupakan mereka yang memiliki dasar pendidikan minimal SMA dan rata-rata pendidikan tinggi berbeda 
dengan buruh yang dasar pendidikannya SD dan SMP, sehingga skor pekerja PNS lebih baik daripada buruh. Pekerjaan lain selain PNS dasar pendidikan lebih bervariasi dan $70 \%$ lebih banyak pendidikan SD dan SMP sehingga pekerja swasta, wiraswasta, buruh, dan IRT memiliki skor lebih rendah. Pekerjaan terbanyak sebesar $42 \%$ responden adalah IRT, sehingga hasil pengetahuan rata-rata di kecamatan Pakisaji kurang.

\section{Jenis Kelamin}

Jenis kelamin di masyarakat pakisaji menunjukkan 64\% perempuan dan $36 \%$ laki-laki dan diketahui skor perempuan lebih

tinggi daripada laki-laki.
Berdasarkan analisis antara jenis kelamin dengan kejadian diabetes mellitus tipe 2, prevalensi kejadian diabetes mellitus tipe 2 pada wanita lebih tinggi daripada laki-laki. Wanita lebih berisiko mengidap diabetes karena secara fisik wanita memiliki peluang peningkatan indeks masa tubuh yang lebih besar. Sindroma

siklus bulanan (premenstrual syndrome), pasca-menopouse yang membuat distribusi lemak tubuh menjadi mudah terakumulasi akibat proses hormonal tersebut sehingga wanita berisiko menderita diabetes mellitus tipe2 (Irawan, 2010).

Perempuan $90 \%$ bekerja sebagai Ibu Rumah Tangga (IRT) sehingga media informasi dari perempuan lebih banyak seperti menonton televisi dan aktivitasnya dalam bidang sosial lebih banyak sehingga proses diskusi dan pertukaran informasi dan pikiran lebih banyak daripada laki-laki.

\section{KESIMPULAN}

Berdasarkan hasil penelitan menunjukkan pengetahuan masyarakat di kecamatan Pakisaji kabupaten Malang tentang resiko penyakit diabetes mellitus masuk kategori kurang dengan karakteristik masyarakat adalah masyarakat yang memiliki usia $>40$ tahun. Faktor resiko diabetes mellitus dibagi menjadi 2 yaitu faktor resiko yang dapat dimodifikasi dan faktor resiko yang tidak dapat dimodifikasi. Faktor resiko yang dapat dimodifikasi antara lain pola makan, aktivitas fisik, stres, merokok, alkohol, hipertensi, dan obesitas, sedangkan faktor resiko yang tidak dapat dimodifikasi yaitu usia, keturunan dan jenis kelamin.

Pengetahuan masyarakat yang mengetahui tentang resiko penyakit diabetes mellitus di kecamatan Pakisaji kabupaten Malang yaitu pola makan, masyarakat yang tahu bahawa pola makan merupakan resiko diabetes mellitus sebanyak 63\%, sedangkan aktivitas fisik $56,5 \%$, Stres $50 \%$, merokok $45 \%$, alkohol 56\%, hipertensi 60\%, obesitas $51 \%$, usia $64,5 \%$, keturunan $78 \%$, dan jenis kelamin $64,5 \%$.

Hasil skor dari 254 responden memiliki rentang skor 28 (benar 4) adalah skor paling rendah atau minimum dan skor 100 (benar 14) adalah skor paling tinggi atau maksimum. Jumlah skor paling banyak (modus) ada pada skor 57 dan 64 (benar 8 dan 9), sedang nilai rata-rata (mean) secara keseluruhan adalah 61,9 (kurang). Persentase

hasil pengetahuan dari 254 responden sebanyak 127 responden atau $50 \%$ yang memiliki pengetahuan kurang.

Ketidakselarasan hasil pengetahuan terjadi karena selain daripada faktor-faktor yang telah 
disebutkan dalam mempengaruhi pengetahuan seperti usia, pekerjaan, pendidikan, yaitu kembali kepada proses terbentuknya pengetahuan pada setiap individu di luar dari tingkat pendidikannya seperti yang diuraikan dalam Notoatmodjo (2010) yaitu pengetahuan adalah hasil penginderaan manusia, atau hasil tahu seseorang terhadap objek melalui indra yang dimilikinya

(mata, hidung, telinga, dan sebagainya). Artinya sangat dipengaruhi oleh intensitas perhatian dan persepsi terhadap objek.

\section{SARAN}

Saran dari penelitian skripsi
yang berjudul Gambaran
Pengetahuan Masyarakat tentang
Resiko Penyakit Diabetes Mellitus di
Kecamatan Paksiaji Kabupaten
Malang" ini, antara lain:

\section{Bagi Kecamatan dan atau Puskesmas Pakisaji}

Dengan ditulisnya skripsi dan penelitian ini diharapkan mampu menjadi acuan yang dapat menggambarkan kondisi masyarakat di kecamatan Pakisaji tentang

pengetahuan terhadap resiko penyakit diabetes mellitus sehingga dapat dilakukan upaya pencegahan dan promosi kesehatan dalam bentuk program atau sebuah kebijakan untuk memperbaiki dan meningkatkan derajat kesehatan masyarakat di kecamatan Pakisaji.

\section{Bagi Jurusan Ilmu Kesehatan Masyarakat}

Dengan ditulisnya skripsi dan penelitian ini diharapkan mampu menjadi salah satu rujukan untuk para mahasiswa jurusan ilmu kesehatan masyarakat baik di Universitas Negeri Malang dan atau
Universitas lain dalam pemenuhan tugas kuliahnya.

\section{Bagi Peneliti Selanjutnya}

Dengan ditulisnya skripsi dan penelitian ini diharapkan mampu menjadi sumber ide kepada penelitipeneliti selanjutnya untuk meneruskan membuat penelitian terkait penyakit diabetes mellitus akan tetapi lebih dikupas secara luas dan mendalam dengan variabelvariabel lain seperti sikap, tindakan dan perilaku.

\section{DAFTAR RUJUKAN}

Badan Pusat Statistik Kabupaten Malang. 2016. Kecamatan Pakisaji Dalam Angka 2015. Malang.

Departemen Kesehatan. 2008. Kurikulum \& Modul Diabetes Mellitus. Jakarta.

Departemen Kesehatan. 2009. Pedoman Teknis Penemuan dan Tatalaksana Penyakit Diabetes Mellitus. Jakarta.

Departemen Kesehatan. 2013. Pedoman Teknis Penemuan dan Tatalaksana Penyakit Diabetes Mellitus. Jakarta.

Dinas Kesehatan Kabupaten Malang. 2016. Profil Kesehatan Kabupaten Malang. Malang.

Erlinawati. 2007. Buku Ajar Ilmu Penyakit Dalam Jilid I. Jakarta: Balai Pustaka.

Fatimah, Restyana Noor. 2015. Diabetes Mellitus Tipe 2. Jurnal Majority Volume 4 Nomor.

Hanifah, Maryam. 2010. Hubungan Usia dan Tingkat Pendidikan dengan Pengetahuan Wanita Usia 20-50 Tahun 2010 tentang Periksa Payudara Sendiri (SADARI). 
Universitas Islam Negeri

Syarif Hidayatullah. Skripsi

Hastuti. 2008. Faktor Risiko

Kejadian Diabetes Mellitus

Tipe 2 Pasien Rawat Jalan

(Studi Kasus di Rumah Sakit

Umum Daerah Sunan

Kalijaga Demak. Tesis

Universitas Negeri

Semarang). (online)

[http:/lib.unnes.ac.id/2428/]

diunduh pada 19 November

2016.

Irawan, Dedi. 2010. Prevalensi dan

Faktor Risiko Kejadian

Diabetes Melitus Tipe 2 di

Daerah Urban Indonesia

(Analisa Data Sekunder

Riskesdas 2007). Universitas

Indonesia. Thesis (tidak diterbitkan).

Irianto, Koes. 2014. Epidemiologi

Penyakit Menular dan Tidak

Menular:Panduan Klinis.

Bandung: Alfabeta.

Kementrian Kesehatan RI. 2007.

Hasil Riskesdas Tahun 2007.

Banlitbangkes.

Kementrian Kesehatan RI. 2013. Hasil Riskesdas Tahun 2013. Banlitbangkes.

Notoatmojo, S. 2007. Promosi Kesehatan dan Ilmu Perilaku. Jakarta: Rineka Cipta.
Notoatmodjo, S. 2010. Ilmu Perilaku Kesehatan. Jakarta: Rineka Cipta.

PERKENI. 2011. Konsensus Pengelolaan dan Pencegahan Diabetes Mellitus Tipe 2 di Indonesia. Jakarta: PB. PERKENI

Puskesmas Pakisaji. 2016. Profil \& Data Kesehatan Kecamatan Pakisaji tahun 2015. Malang.

Sanjaya, I Nyoman. 2009. Pola Konsumsi Makanan

Tradisional Bali sebagai

Faktor Risiko Diabetes Melitus Tipe 2 di Tabanan. Jurnal Skala Husada Vol. 6 No.1 hal: $75-81$

Siregar, Sofyan. 2012. Statistik Deskriptif untuk Penelitian. Depok. Rajagrafino Persada.

Situmorang, Siska dkk. 2009. Gambaran Pengetahuan Masyarakat Kota Medan Mengenai Penggunaan Obat Antijamur Topikal. E-Journal FK USU Vol.1 No.1.

Tjokroprawiro, Askandar. 2006. Diabetes Mellitus Klasifikasi, Diagnosis, dan Terapi. Jakarta: Gramedia Pustaka Utama.

World Health Organization. 2016. Global Report on Diabetes. Geneva. 